DOI: 10.19195/0137-1150.163.52

\author{
JAKUB ČĔ̌KA \\ Univerzita Karlova v Praze, Republika Czeska \\ ceska@fhs.cuni.cz
}

\title{
Literatura a stáŕín
}

\section{Stáří v síti fikce}

Co si vůbec počneme s tématem stáří, které odkazuje daleko spíše k životnímu faktu než k faktu literárnímu? Máme jej chápat tak, že do literatury stáří jaksi přirozeně prosvítá? Máme mu tedy rozumět jako jisté variantě vulgárně chápaného mimetismu, který nalezl u autorů sjednocených pod doktrínou teorie fikčních světů celou řadu odpůrců? Je to tudíž vůbec teoreticky obhajitelná pozice, v níž bychom se snažili pochopit literaturu jako poměrně neproblematickou meditaci nad okolnostmi života? Zachovala by si poté vůbec svoji svébytnost, svůj raison d'être? Nerozpustili bychom ji ve faktech života, které mohou být zkoumáný adekvátnějšími př́stupy (v oborech spřízněných s medicínou, v sociologii, výzkumy, které se zaměřují na zkvalitnění lidského života ve stáří atp.), než jaké nám nabízí bytostně metaforický jazyk literatury? Nemá tedy literatura důležitější věci na práci než to, aby kroužila kolem faktických okolností života, když úsilí tvůrců směřuje především k tomu, aby výsledný umělecký tvar dovedli k co možná největší dokonalosti?

\section{Amorfnost života a strohost literatury}

Zatímco život je svojí povahou amorfní, nevidíme a ani si nijak neuvědomujeme jeho začátek a konec, literární dílo naopak nabízí artikulované pole se zřetelně vyznačeným začátkem a koncem. Alespoň takto vypadá valná většina literárních děl, nebot' začátek i konec vyprávění jsou klíčové pozice literárního díla, a to jako vstupní iniciační brána (o úvodních větách románu by bylo možné napsat rozměrnou studii) a jako závěr románu, v němž může dojít $\mathrm{k}$ zásadnímu přehodnocení do té doby inscenovaného smyslu.

* Autor byl při práci na tomto článku podpořen grantem GA ČR č. 15-07592S Bohumil Hrabal-autor v množném čísle. 


\section{Mládnutí literatury a stárnutí života}

Život se od literatury liší svojí formální stránkou. Stárnoucí a zastaralá literatura se pro současného čtenáře vyznačuje archaismy: stárnutí, zastarávání nebo stáŕí je poměřováno aktuálním stavem jazyka. To však neplatí pouze pro lexikum, gramatické tvary, infinitivní koncovky atp., nýbrž také pro vypravěčské postupy - pro výběr způsobu vyprávění, jeho tempa, přítomnosti či nepř́itomnosti digresivních pasáží, specifičnosti tematické osnovy atp.

Ve vývoji uměleckých prostředků můžeme sledovat snahu tvůrců o inovaci. Takto dílo kdysi formálně inovativní se posléze stává součástí kánonu. Osudem inovace je zastarávání, revoluční dílo otevřelo cestu, kterou lze poté již snadno opakovaně projít. Takové dílo bude posléze pocitováno jako strojené, zastaralé a nesoučasné. Snaha umělců o inovativní formální postupy je př́činou literárního vývoje, který vykazuje obrácený pohyb než život: umění mládne, život stárne. Zaměříme-li se ovšem na přežívání rodu, mohlo by se zdát, že také v životě ti později narození obrozují staří těch ustupujících ze světa. Ovšem lidský rod obnovovaný $\mathrm{v}$ potomcích nevybočí z horizontu biologických rytmů, a proto také obtížně zahlédneme v nastupující generaci vlastní nesmrtelnost.

Život se vyznačuje změnou, nestálostí, těkavostí, literatura naopak svým definitním tvarem, který má jistou setrvačnost. Zatímco lidský život je poznamenán mizením, literatura je typická svojí statičností, svojí rezistencí vůči změnám. Arendtová ${ }^{1}$ chápe zhotovování uměleckých děl jako jeden ze způsobů, jímž lze vykročit za horizont biologického života.

\section{Pomíjivost života a nesmrtelnost literatury}

Díky konzervativní povaze literatury bývá také občas spojována $\mathrm{s}$ nesmrtelností: literární díla $\mathrm{k}$ nám promlouvají také ve chvíli, kdy jejich autoři nejsou mezi živými.

Ne náhodou věnuje Milan Kundera nesmrtelnosti ve smyslu neměnnosti literárních gest, která jsou nečasová, nadčasová a věčně mladá, rozsáhlý stejnojmenný román. Uvádí v něm provokativní tezi, podle níž se o nás naše nesmrtelnost nestará, zatímco my o ni ano, podobně jako se staráme o to, co si o nás druzí myslí.

Starost o nesmrtelnost je možná pouze díky cíleně utvářeným uměleckým dílům, která jsou nadána zmíněnou setrvačností. Pokud se vrátíme k úvodnímu vymezení, pak ve snaze zachovat literaturu při životě narůstá její tělo, zatímco život pozvolna a téměř neviditelně mizí ze světa. Třebaže narůstá počet obyvatel, je tento počet vymezen na nerozlehlém časovém hřišti ne o mnoho větším než sto let.

Rozměrné tělo literatury se vyznačuje neporovnatelně větší rozlohou (od současníků až kamsi k Homérovi, Hesiodovi atp.), proto také kultura poskytuje životu pevnější ukotvení, než jaké by si mohl poskytnout sám život. Teprve vztahem ke

${ }^{1}$ H. Arendtová, Vita aktiva neboli O činném životě, přel. V. Němec, Praha 2009, s. 28-30. 
kultuře a umění se lidská bytost vyvazuje z biologických rytmů a z nevyhnutelného zániku. Zatímco literatura vrůstá do svého mládí, lidská bytost naopak př́liš brzy vrůstá do svého stář́ a do svojí smrti. Gnómicky to vyjádřil Samuel Beckett v Čekání na Godota: „Rodí obkročmo nad hrobem, na okamžik zazáŕí den a nanovo je noc."

Pouze takové umělecké směry, které přijímají tradici jako výzvu tvaru, se nerozplynou $\mathrm{v}$ efemérní, zaslepené a $\mathrm{v}$ neposlední řadě lyrické revoltě, kterou ovládá biologické mládí.

\section{Tradice - ukotvení uměleckého díla}

Podle Milana Kundery má dílo romanopisce cenu pouze potud, pokud spisovatel sveřrí svůj hlas románové tradici. ${ }^{2}$ Kunderova nevraživost není namířena na inovaci v uměleckém stylu, kompozici, vypravěčské perspektivě (jak jinak by mohl první monografii věnovat Vladimíru Vančurovi, pro něhož hrála inovace tvůrčích postupů klíčovou roli³), kterou nová historická situace nutně přináší, nýbrž je zacílená na revoluční požadavky modernistů, kteří sami sebe chápou jako zcela nový počátek umění. Inovace má svoji razanci a sílu teprve ve chvíli, kdy v sobě zahrnuje předchozí tradici. Zralost (či dospělost) je tudíž spjata s pevným zakotvením v tradici.

\section{Trable s lyrikou}

Milan Kundera zavrhuje modernistický projekt literatury, nebot' jej považuje za do sebe zahleděný, odtržený od literární tradice, zároveň však také za lyrický. Přitom lyrika je pro Kunderu reflexním mementem jeho tvorby. Lyrika pro Kunderu ovšem nepředstavuje pouze jeden z prvků žánrové triády, nýbrž především určitý životní postoj, který je pro Kunderu neodmyslitelně spjat s mládím. Třebaže můžeme původně chápat lyriku jako jeden z projevů mládí, není poté mladým ten, kdo se zaklíná lyrikou (nebo ten, kdo podlehl jejímu kouzlu)? Mládí je funkcí literatury, což Kundera v Životě je jinde komentuje následovně:

Mládí netuší, jaká je to velmoc, být mlád. Ale básník (je mu asi šedesát let), který ted’ povstal, aby zarecitoval svou báseň, to ví.

Mladý je ten, přednášel zpěvavým hlasem, kdo jde s mládím světa a mládí světa je socialismus. Mladý je ten, kdo je ponořen do budoucnosti a neotáčí se zpátky.

Řekněme to jinými slovy: V pojetí šedesátiletého básníka nebylo mládí označením určitého věku, nýbrž hodnotou, která nemá nic společného s konkrétním věkem. Taková myšlenka pěkně zrýmovaná splňovala nejmíň dvojí poslání: Jednak zalichotila mladému publiku, zadruhé zbavovala básníka magicky jeho vrásčitého věku a přiřazovala ho (nebot'

${ }^{2}$ M. Kundera, Jeruzalémský projev: Román a Evropa, [w:] idem, Zneuznávané dédictví Cervantesovo, Brno 2005, s. 36-37.

${ }^{3} \mathrm{~K}$ tomu srov. M. Kundera, Uméní románu. Cesta Vladislava Vančury za velkou epikou, Praha 1960. 
bylo nade všechny pochyby, že kráčí se socialismem a neohlíží se zpět) k mladým dívkám a chlapcům (Život je jinde, díl 4., 12. kapitola).

\section{Stáří ve službách mládí}

Právě v Kunderově konceptu lyriky se setkává literatura s životem, a to ve specifické patetické životní póze. Třebaže je tématem konference stáří, exkursem k lyrice, se pokouším zdůraznit, že v literatuře je mládí (stejně jako stáŕí) funkcí literatury. Stáŕí tudíž není neproblematickým a na literatuře zcela nezávislým životním faktem. Proto také není rozhodujícím věk postavy, nebot' mládí je funkcí lyriky, podobně, jako když šedesátiletý básník odvozuje mládí z příklonu k poezii, levici a budoucnosti. Vzpomeňme také na Paula, manžela Agnes (Nesmrtelnost), jehož vypravěč, navzdory jeho zralému věku, označuje jako lyrickou postavu. Mládí je zaslepené, nebot' trpí dojmem, že tu před ním nic nebylo, a proto se dívá pouze dopředu, což pro něj značí, že se vzhlíží v zrcadle.

\section{Dvojí zaslepení básníka — tone v sobě a svět si cloní poezií}

Jelikož se hodlám věnovat především dílu Milana Kundery, s dílčími výhledy k dílu Bohumila Hrabala, definuji nejprve mládí vztahem k lyrice, která v Kunderově díle představuje svéráznou kontaminaci etického a estetického postoje. Jazyk jako by mohl bezprostředně a takříkajíc s radostí vstoupit do služeb básníkova nitra, aby jej vystavil v celé kráse. Lyrika se vyznačuje dojmem bezprostředního vztahu k nitru básníka, zároveň ale také imaginativním a tudíž také zprostředkovaným a tvůrčím vztahem ke skutečnosti. Tento dvojí a dvojznačný vztah (jájazyk, jazyk-svět) stvrzuje zaslepení, nebot' já, které se vzhlíží v zrcadlech své poezie, si svět zkrášluje. Lyrik je vězněm sebestřednosti a poezie, která nemůže nastolit adekvátní či stř́żlivý vztah ke skutečnosti.

\section{Dospělost — zrození románu v rozvalinách lyriky}

Kunderův vstup na pole literatury na počátku padesátých let (nebo na konci let čtyřicátých) je spojen s entuziasmem mládí a invazí lyriky. Proto také charakterizuje Milan Kundera dospělost odklonem od lyriky a př́klonem k románu. Zrání je zde opět funkcí literatury, nikoli naopak, nebot' někdo může v lyrickém věku setrvávat navzdory svému pokročilému věku. Vyznačuje-li se mládí lyrikou, rodí se román či románová zkušenost na troskách lyrického věku.

\section{Svět románů Milana Kundery — zestárneme bez dětí?}

Přestože bych měl mluvit o stáří, stále se mi vnucuje tematika dětství, nezralosti, což můžeme v jistém ohledu chápat jako ukradené stáří. Současná doba už patrně nabízí jiný obraz mládí a stárnutí, než jaký svým dílem odhaluje Milan 
Kundera, i když ještě v nedávno vydaném románu Benoît Duteurtre Holčička a cigareta se svět rrídí patetickým heslem „Vše pro dítě”. Trauma z tyranské vlády dětí, a to nejenom v doslovném slova smyslu, ale také v metaforickém, nebot' dítě tot' klíčové slovo kýče, je patrné ještě v posledním Kunderově románu Slavnost bezvýznamnosti. V něm syn rozmlouvá s fotografí́ svojí matky, která jej opustila, když mu bylo dvanáct let. Tyto „rozhovory” se otáčejí kolem záhady, proč se jeho matka odmítla podílet při navazování řetězu generací. Kunderův románový svět je především světem bez dětí. Proto také stáří či stárnutí bude mít svoji specifickou podobu.

Zahlíží-li Milan Kundera na vládu dětí, současnost bychom mohli charakterizovat především jako svět sirotků, a to nejenom ve vztahu k předchozí generaci, nýbrž také ve vztahu ke kultuře a k elitám.

Vyznačuje-li Milan Kundera dospělost erozí lyrického věku a zrozením romanopisce, je otázkou, jestli obdobným způsobem můžeme vyznačit stáří. Vyhneme-li se mimoliterárním kritérí́m, můžeme se stáŕí pokusit charakterizovat s ohledem na proměnu autorské poetiky. Jeden znak přerodu raného a středního období románové tvorby Milana Kundery v tvorbu pozdní můžeme vidět ve stř́idání dominantního organizačního principu od metaforičnosti (raná a stř̌ední románová tvorba) $\mathrm{k}$ metonymičnosti. ${ }^{4}$ Mezi prvním románem Žert dopsaným roku 1965 a prozatím posledním románem vydaným roku 2013 nezeje tedy pouze téměř padesátiletá propast, nýbrž také přerývavý vývoj autorské poetiky. Kunderova románová tvorba má zjevně svoje vrcholy a naznačené nové směry, třebaže se její autor zaměřuje na několik základních témat, nevyvíjí se jeho poetika zcela přímočaře. Tematika stáří se nám nyní odvíjí na rovině literárního druhu a specifického vztahu spisovatele ke své tvorbě.

\section{Hrabalova tvorba ve tvaru Gaussovy křivky}

Jako kontrastní příklad ke Kunderovu vyhraněnému spisovatelskému naturelu si dovolím uvést dílo Bohumila Hrabala, a to nejen kvůli tomu, že oba vstupují na pole umění lyrikou, nýbrž také proto, že u obou autorů probíhá specifický zápas o výsledný umělecký tvar, přitom osud každého $z$ autorů je značně odlišný a to také ve vztahu ke stáŕí. Tvorbu Bohumila Hrabala můžeme totiž přirovnat ke Gaussově křivce. Jeho tvorba sice začíná poezií, ale s Hrabalovým sklonem k surovému výrazu, lehké pornografii a ironii se nejedná o tesklivou lyriku. Hrabalova tvorba dosahuje svého vrcholu (po počáteční povídkové tvorbě z padesátých a první poloviny šedesátých let) $\mathrm{v}$ románech z první poloviny sedmdesátých let: Hlučná samota, Obsluhoval jsem anglického krále, Něžný barbar, Městečko, kde se zastavil čas. Z tvưrčího vrcholu poté autor sestupuje do specificky vedeného, vnitřně fokalizovaného a do jisté míry ideově přehledného vyprávění: $\mathrm{k}$ trilogii

${ }^{4} \mathrm{~K}$ tomu srov. J. Češka, Metonymická motivace v pozdní románové tvorbě Milana Kundery, [w:] idem, Průzračnost tvorby v zrcadle literatury, Praha 2014, s. 71-86. 
z první poloviny osmdesátých let (Svatby v domé, Vita Nuova, Proluky). V ní se jistým způsobem vrací k narativní formě jedné z prvních próz — ke Kainovi (1949). Formu pro tuto novela s netypicky silným a sebevědomým vypravěčem si Hrabal vypůjčuje z Camusova Cizince ${ }^{5}$.

Zmíněnou trilogií z poloviny osmdesátých let vymezuje Jiří Pelán Hrabalovo dílo, nebot's nástupem Hrabalovy „literární publicistiky” z konce osmdesátých let a začátku devadesátých let dochází podle Pelána k regresi a úpadku. ${ }^{6}$ Snahou o náčrt trajektorie Hrabalova díla jej nemám v úmyslu hodnotit. Jde mi pouze o vyznačení jeho obecných tendencí. Můžeme jej vymezit počáteční expanzivní lyrikou a dohasínající lyrickou sebelítostí „literární publicistiky.”7 Teprve v ní se Hrabal odvažuje plnou měrou vyslovit svoje já, které, ač by s tím možná ne každý souhlasil, nebylo prvořadým tématem jeho díla.

Tudíž Hrabalova tvorba jako by kopírovala tvar Gaussovy křivky: rodí se z lyriky, aby se vzepjala do výšin vrcholné tvorby sedmdesátých let (do ní bych zařadil pozdější hororové ${ }^{8}$ Harlekýnovy milióny, v nichž je navíc hlavním tématem právě stárnutí a smrt), poté začne sestupovat k trilogii, a posléze se rozpouští v př́liš osobním psaní literární publicistiky. Hrabalova tvorba plní roli integrujícího a stabilizujícího prvku, k němuž se upíná jeho život. Dokonce to svádí $\mathrm{k}$ domněnce, že smrt nastává tehdy, až je dílo hotovo. Pamětníci vzpomínají na poslední období Hrabalova života, kdy se opakovaně vrací k tomu, že vše, co zamýšlel napsat, už napsal.

Jinou linii opisuje dílo Milana Kundery, o němž můžeme říci, že se od prvních básnických počátků vevazuje nejprve do tradice románu, aby posléze setrvávalo $\mathrm{v}$ jeho osudí, přitom si však jejich autor volí osobitou a soustředěnou cestu, která v prozatím posledním románu La fête de l'insignifiance nabízí enigmatické zrcadlo a šifru celé předchozí tvorby. V Kunderově díle můžeme tedy sledovat vyzrávání tvaru, jeho krystalizaci, kde i pozdní dílo je mládím tvorby ve smyslu jeho inovativního přepsání. V Hrabalově díle můžeme naopak sledovat ústup ke sdělnosti. Návratu lyričnosti Hrabalovy „literární publicistiky” ovšem schází tolik potřebná krajina teprve tušeně se otevírající budoucnosti. Lyrika potřebuje ke své vehementní přehnanosti mladé tělo a neurčitý, do daleka se táhnoucí lán času.

5 B. Hrabal, O Kainovi, [w:] Kdo jsem, Sebrané spisy Bohumila Hrabala, sv. 12, Praha 1995, s. $284-285$.

${ }^{6}$ J. Pelán, Bohumil Hrabal: Pokus o portrét, Praha 2002, s. 68-69.

${ }^{7}$ Milan Jankovič se naopak snaží v Hrabalově pozdním díle ukázat jeho specifičnost a svébytnost, tím také doložit jeho literární kvalitu (M. Jankovič, Kapitoly z poetiky Bohumila Hrabala, Praha 1993, s. 147-155).

${ }^{8}$ V závěru Harlekýnových milionů se ze stařičké maminky Bohumila Hrabala stává přízrak (živoucí mrtvola), což si uvědomuje podle toho, že ji žijící bytostí nevidí, ani neslyší, zatímco ona se přátelí s bytostmi dávno již mrtvými. Ještě mnohé další důvody bychom mohli uvést (především závěrečnou scénu v zámeckém skleníku, který sloužil jako márnice), abychom tento román charakterizovali jako hororový. 


\section{Lidé stárnou, románové postavy mládnou}

Lidé stárnou, románové postavy nepodléhají nástrahám času (nestárnou). Jelikož lidé stárnou, zatímco postavy zůstávají stejně staré, můžeme nabýt dojmu, že naopak mládnou. Při prŕípravě autorizovaného vydání v polovině osmdesátých let udělal Milan Kundera drobnou změnu v původním názvu povídky Doktor Havel po deseti letech, kterou změnil na Doktor Havel po dvaceti letech, ${ }^{9}$ snad proto, aby zachoval časové proporce mezi sebou a svými postavami. Také tuto dílčí změnu můžeme chápat jako jeden $\mathrm{z}$ dokladů mládnutí postav. $\mathrm{K}$ tomu, aby románové postavy zůstávaly stejně staré, by je museli jejich autoři stále průběžně činit stále staršími.

Pro spisovatele postavy mládnou, pro čtenáře naopak jejich autoři nestárnou. Patrně nelze stanovit stáŕí fikce, od čeho bychom jej vůbec mohli odvodit? Nepůsobí ostatně fikční scéna literárního díla jako zrcadlo vlastního času? Kdysi jedna studentka, která četla Nesmrtelnost (bylo to na konci devadesátých let), byla překvapená, když jsem jí řekl, že Goethův věk v románu (62 let) je jen o dva roky vyšší než věk autora románu ve chvíli, kdy jej dokončoval. Romanopisce si představovala jako mladého člověka, zatímco Goethe byl pro ni v Nesmrtelnosti už „starý”. Bylo by unáhlené přičíst tento optický klam pouze fyzickému zjevu Goetha v Nesmrtelnosti (,nemá už ani jeden zub” ${ }^{10}$ ), což by nás přivedlo k neliterárnímu faktu, navíc v současnosti se hranice stáŕí posouvá stále více do pokročilejšího věku. Nás zde zajímá ovšem specifické stáří, které jako čtenáři přiřkneme specifické iluzivní perspektivě literárního díla. Pokud sami sebe pocitujeme jako současníka iluzivního světa románu, budeme mít patrně tendenci považovat autora díla za svého vrstevníka.

Konzervativní rys fikce a také jeho iluzivní perspektiva vytvářejí jistou časovou deformaci. At’ již jsme mluvili o mládnutí postav nebo jsme byli svědky čtenářova nesouhlasu s věkem autora. Nyní uved'me poslední př́íklad. Milana Kunderu překvapilo, že románové postavy Dostojevského románu Idiot jsou mladší než v jeho vzpomínkách. Přičítá to tomu, že Dostojevský nám vypráví drama lidských bytostí, nikoli drama mladosti ${ }^{11}$. Zde může hrát roli zmiňovaný efekt mládnutí postav, dále stáří autora (Dostojevského) a jeho mentální věk, kterým převyšuje své postavy, v neposlední řadě také specifické a problematicky stanovitelné stáří iluzivní perspektivy daného díla.

K tomuto perspektivnímu klamu tudíž přispívá i to, že mladé postavy modeluje zralý autor, intelektuální a kulturní obzor postav může sahat tak daleko, kam sahá obzor jejich autora. Což platí zejména u Dostojevského, pro něhož je románová postava rovnocenným partnerem v dialogu, někým, s kým jako spisovatel vede při, jako by hrál šachy sám se sebou a poskytoval tudíž svému alter egu — románové postavě jako protihráči — veškerý svůj um. ${ }^{12}$

${ }^{9}$ F. Ricard, Biographie de l'œuvre, [w:] M. Kundera, Euvre I, Paris 2011, s. 1410.

${ }^{10}$ M. Kundera, Nesmrtelnost, Brno 1993, s. 51.

${ }^{11}$ M. Kundera, Le Rideau, [w:] idem, Euvre II, Paris 2011, s. 1036.

$12 \mathrm{~K}$ tomu srov. M. Bachtin, Hrdina a postoj autora $k$ hrdinovi, [w:] idem, Dostojevskij umělec, Praha 1971, s. 65-105. 


\section{Staří jsou ti druzí}

„Mládnutî” románových postav svědčí také o bytostné vztahovosti stáŕí: staří jsou ti starší než my sami. S přibývajícím věkem proto posouváme hranici stáří stále do vyššího věku. „Já” není nikdy staré, nebot' staří jsou ti druzí. Stárúi definujeme vztahem $\mathrm{k}$ tomu, kdo je o mnoho let starší, ledaže bychom přejali perspektivu druhých, kteří by nám chtěli vnutit perspektivu svého mládí. „Já” zestárne teprve $\mathrm{v}$ budoucím čase, a tudíž se může zdát, že nebude nikdy staré. Dvojznačnost stáří, která spočívá ve víceznačnosti přejímané perspektivy, přesvědčivě líčí v jednom esejistickém textu Bohumil Hrabal: ,Jaryna se tolik těšil na setkání po padesáti letech všech spolužáků, kteří ostali na světě, a bylo to setkání, ve kterém se jeden každý cítil mlád, a přesto ty ostatní viděl jako starce a stařeny nad hrobem."13 Obdobně líčí stáří maminka Bohumila Hrabala v Harlekýnových miliónech, nebot' i ona se nemůže ve stáŕí nejprve poznat, zatímco o stáří obyvatelů domova důchodců vůbec nepochybuje.

\section{Tělo stárne, věčně mladá a nesmrtelná jsou gesta}

Ani v románech Milana Kundery nemá stář́ pevně stanovenou hranici. Počínající pleš ohlašuje starému mládenci z povídky „At’ ustoupí staří mrtví mladým mrtvým"14 jeho první bilanční setkání se sebou samým, přitom je mu třicet pět let. Jeho známá (před patnácti lety s ní strávil noc) je pro něj beznadějně stará (je jí padesát), vidí ji zamřížovanou stářím (vrásčitý krk, staré ruce, rukou nahmatává $\mathrm{v}$ ústech její chybějící zuby). $\mathrm{K}$ tomu, aby ji byl schopen poznat jako tu kdysi mladou a přitažlivou, $v$ tom mu překáží konkrétnost jejího stárnoucího těla. Identifikovat ji může teprve prostřednictvím půvabných gest. Milan Kundera odhaluje gesta jako bytostný rys lidské totožnosti. Gesta, podobně jako literatura, sídlí mimo čas. A právě proto, že jsou nečasová, v nás mohou vyvolat pocit náhlého stesku (nebot' nám zpř́itomňují to zašlé, minulé a navždy ztracené). Postačí gesto stárnoucí ženy, aby hostitel za bytostí zamřížovanou stářím zahlédl její mládí. Jsou-li gesta pamětí mladého těla, může také literatura jako arzenál četných literárních gest uchovávat pamět' mládí. Literatura omlazuje, nebot' je svázána s tím nadindividuálním, kulturním, s tím, co vzdoruje zániku. Pochopitelně, že ani literatura neodvrátí zánik lidské bytosti, přesto ale udržuje spisovatele a jeho čtenáře v magickém kruhu literatury, která je mládím jejich stárnutí. Přesně to vyjádřil Bohumil Hrabal ve svém meditativním textu Rukovět pábitelského učně, když napsal: ,jsem mládím těhotný pán, který už stárne." 15

13 B. Hrabal, Sešitek nerozlišujicí pozornosti, [w:] idem, Kdo jsem..., s. 46.

${ }^{14}$ M. Kundera, Směšné lásky, Brno 1991, s. 121.

15 B. Hrabal, Rukovět pábitelského učené, Sebrané spisy Bohumila Hrabala, sv. 8, Praha 1993, s. 187. 


\section{Bibliografie}

Bachtin M., Hrdina a postoj autora k hrdinovi, [w:] idem, Dostojevskij umělec, Praha 1971.

Češka J., Metonymická motivace v pozdní románové tvorbě Milana Kundery, [w:] idem, Průzračnost tvorby $v$ zrcadle literatury, Praha 2014.

Hrabal B., O Kainovi, [w:] idem, Kdo jsem, Sebrané spisy Bohumila Hrabala, sv. 12, Praha 1995.

Hrabal B., Rukovět pábitelského učené, Sebrané spisy Bohumila Hrabala, sv. 8, Praha 1993.

Hrabal B., Sešitek nerozlišujíci pozornosti, [w:] idem, Kdo jsem, Sebrané spisy Bohumila Hrabala, Sv. 12, Praha 1995.

Jankovič M., Kapitoly z poetiky Bohumila Hrabala, Praha 1993.

Kundera M., Jeruzalémský projev: Roman a Evropa, [w:] M. Kundera, Zneuznávané dědictví Cervantesovo, Brno 2005.

Kundera M., Le Rideau, [w:] idem, Euvre II, Paris 2011.

Kundera M., Nesmrtelnost, Brno 1993.

Kundera M., Směšné lásky, Brno 1991.

Kundera M., Uméní románu, Cesta Vladislava Vančury za velkou epikou, Praha 1960.

Pelán J., Bohumil Hrabal: Pokus o portrét, Praha 2002.

Ricard F., Biographie de l'œuvre, [w:] M. Kundera, Euvre I, Paris 2011.

\section{The aging and literature}

\section{Summary}

This contribution is focused on the specific reflection of the theme (aging) in Milan Kundera's and Bohumil Hrabal's work. During the reflection on their poetics and pursuit of its evolving, we can see to what extent the aging (or youth) is a function of literature. Literature and life are distinguished by the opposite characteristics which lead us to consideration that literature provides anchor for life. Literature is eternal youth of irrecoverably disappearing life.

Keywords: thematic Analysis, poetics, Milan Kundera, Bohumil Hrabal, aging

\section{Staroba a literatúra}

Resumé

Témou príspevku je špecifické zmocňovanie sa tématiky staroby u Milana Kunderu a Bohumila Hrabala. Pri reflexii ich poetiky a pri sledovaní ich vývoja sa ukazuje, nakol’ko je staroba (či mladost') funkciou literatúry. Literatúra a život sa vyznačujú opačnými charakteristikami, ktoré nás privádzajú k úvahám, že práve literatúra poskytuje životu ukotvenie. Literatúra je večnou mladost’ou nenávratne miznúceho života.

Klúčové slová: tematická analýza, poetika, Milan Kundera, Bohumil Hrabal, starnutie 